\title{
Development of Learning Tools Based on Realistic Mathematics Education Aproaches to Improve the Mathematical Problem Solving Skills at X Grade in High School
}

\author{
M Arrahmah ${ }^{1 *}$ E Musdi $^{2}$ \\ ${ }^{1}$ Student of Master Program Biology Education, Math and Natural Science Faculty, Universitas Negeri Padang, \\ Padang, Indonesia \\ ${ }^{2}$ Biology Department, Math and Natural Science Faculty, Universitas Negeri Padang, Padang, Indonesia \\ *Corresponding author. cacamawaddaharrahmah@gmail.com
}

\begin{abstract}
The purpose of this research is to describe the effectiveness of learning devices based on RME approaches, improving students ' mathematical problem-solving skills through a developed RME-based learning tools, and student response to RME-based learning devices developed for high school class X learners. Learning devices developed in the form of learning Leson Plan and student Worksheets. This type of research is development research. The model of development used is a Plomp model consisting of three stages that is preliminary research, stage of development or the development or prototyping phase, and assessment phase. In this section the researcher only discusses about research at the preliminary research. At this early investigative stage, researchers used several instruments in the form of validity test sheets, practical test sheets, and an introductory test sheet. Data analysis results show that students ' mathematical problem solving skills are still low because learning devices do not yet support learners to improve their problem solving skills, the learning process still Focused on so that there has been no visible interaction between teachers and students as well as fellow learners, less engaged learners in the learning process.
\end{abstract}

KeyWord: Learning, RME, mathematical problem-solving.

\section{INTRODUCTION}

Education cannot be separated in the development process of the country. Through the development of science and technology education will be easily absorbed, allowing a nation and country to advance. Mathematics is a science that has an important role in the development of science. Mathematics is able to educate people to think logically, critically, systematically, thoroughly, effectively, thoroughly, and can develop creativity. In the learning of mathematics has the concepts that are interconnected with each other, this is because to master a new concept in the mathematics of learners must be able to understand other concepts related to Materials learned. In addition, mathematics can also not be separated from the problems that occur in everyday life.
Based on an interview with a mathematics teacher at SMAN 1 Ampek Angkek Agam District, it is known that there was not yet another RME-based learning tool that can are teachers for the learning process, the handbook available at The library was limited. Teachers have not developed learning devices (modules, Worksheets, handouts) that can help students in the learning process due to time constraints. Learning is more focused on the use of package books in schools. As for Worksheets teachers are Worksheets obtained by the teachers during training, but the obtained Worksheets is rarely used. The reasons for Worksheets are lacking in accordance with the characteristics of learners. Teachers tend to present material based on package book. The exercises that teachers give to learners are also more focused on textbooks. Learners of passive nudge in mathematics learning. Learning becomes less interesting because the package book is unable to meet the diverse needs and characteristics of the learners. This can be seen from the 
average daily replay value gained by learners is far below the minimum standards of submission.

The lack of achievement of mathematical learning outcomes is due to the learners paradigm of mathematics learning. Based on interviews with some learners, there is information that a large number of learners do not like math because mathematics is a difficult lesson and has many formulas. Learners think math lessons are not important because of the lack of understanding of the use of mathematical lessons in the life of learners. This resulted in the learners less interested or passive in learning mathematics. In addition, learners complained about the lack of the book libraries, as well as textbooks with only one limited number of publishers and not enough for all learners.

Basically the application of varied learning methods and the development of appropriate teaching materials can improve students ' success in the learning process. To be able to implement teacher learning is required in order to develop teaching materials that fit the needs of students, student characteristics and teaching material characteristics, because only you know the needs and characteristics of participants.

Based on the descriptions described above, it can be concluded that in order to make mathematical lessons a meaningful lesson and form the self-reliance of students in learning, the learning activities must be arranged in such a way. Learning is a systematic process of developing several components including teachers, learning devices, students, learning and assessment processes. This means that learning devices are one component of the learning process. For that, a varied learning tool is needed to allow learning in the classroom and the learning process to run well. Every teacher in an education unit should be able to organize learning devices, so that learning can form the independence of students, and train and improve the critical thinking skills in solving problems is to use the model (RME) based on Realistic Mathematics Education.

RME is a learning approach that is used only in mathematics education. According to Soedjadi the realistic approach emphasizes the utilization of the reality of life or the local culture as a starting point of learning. Furthermore, it is also explained that reality is a real or concrete thing that can be observed or understood by learners by imagining. It can be concluded that learning with the RME approach utilizes the surrounding environment around students, both school environment, family environment, and community environment.

In Wijaya, Treffers formulated five characteristics of RME, namely: the use of context, the use of models for progressive mathematics, the utilization of students ' construction results, interactivity, and the linkage of mathematical concepts. Based on these characteristics can be drawn relevance between RME and the mathematics curriculum in Indonesia.

In the research that will be done development of mathematics learning devices directed to produce lesson Plan and Worksheets based RME products to improve the mathematical problem solving skills that are already relevant to the 2013 curriculum in Odd semester material.

On the other hand, learning device development should also pay attention to the local potential. This is in accordance with Government regulationsNo. 19 year 2005 on National Education Standards Article 17 mention that the curriculum was developed according to the Unit of education one of which is based on the potential area/regional characteristics. Therefore, the process of integrating the material with the surrounding environment into the development of learning devices to form the learning outcomes of students who have a disaster alert as enrichment materials. As Regulation of ministerial No. 3 of 2008 stated in the plan of learning, it must contain enrichment materials. So integrating teaching materials with potential regional/regional characteristics through enrichment materials to learners is a curriculum requirement. Starting from the description, the author intends to undertake research under the title

"Development of Learning Tools Base on Realistic Mathematics Education's To Improve The Mathematical Problems Solving Skills at X Grande In High School”.

\section{MATERIALS AND METHODS}

Research conducted on this research is development research. Sugiyono stated that development research is a method of research used to produce a specific product, and to develop the effectiveness of the product. According to Plomp \& Nieven, development research consists of three phases: the preliminary Research, phase of development or manufacture of prototype development or prototyping stage, and assessment stage. In the preliminary research there are some activities undertaken that are conducting the need analysis, curriculum analysis, concept analysis and student analysis. The result of the initial investigation is used as the basis for developing learning devices to be designed. The prototype stage is the product development process developed based on the results of, preliminary research or initial investigation. The prototype covers the design, development and formative evaluation of activities. It is done at this stage namely product development of Lesson Plan and Worksheets based RME. Formative test at the development stage is conducted through evaluation of one to one, small group and field test. The formative 
evaluation phase is conducted by evaluating the content or format of the products designed based on formative test results. In the evaluation phase, the assessment phase of the revised result of the prototype is to carry out a practical test and effectiveness test in large groups/limited trials. The evaluation carried out at this stage is conducted semisumative evaluation.

\section{RESULT AND DISCUSSION}

The student's analysis was conducted to: (1) Gather information on fundamental and general problems in mathematics learning, (2) know the level of need for RMEbased learning devices to improve The mathematical problem-solving skills of learners, (3) know the characteristics of learners and their relation to the characteristics and principles of RME. This activity is done by observing the process of mathematics learning in SMA Negeri 1 Ampek Angkek. Based on observations and interviews with mathematics teachers, there is information that the learning process in the classroom is still centered on the teacher and has not been in accordance with the 2013 curriculum. The willingness of learners to learn is still low, learners are inactive and less enthusiastic about learning because they only accept what teachers explain in the learning process. Existing lesson Plan teachers are not realised in learning. Teachers do not use self-designed Worksheets or Worksheets from publishers.

To see the ability of learners, researchers also give tests on mathematical problem solving skills. Based on the analysis of the test, obtained information that the skills of mathematical problem solving the learners are still low. The collected Data is used as a reference in the development stage or making prototype.

The characteristics of learners are one of the considerations that must be considered in drafting a learning tool. One of the ways that can be done knowing the characteristics of learners is to do the analysis. According to Thiagarajan the student analysis is a study of the characteristics of the students that correspond to the design of learning device development. Student analysis is conducted to know the characteristics of learners in relation to academic ability, student environment, the tendency of learners to learn, teaching materials like what learners, ability of participants Students in mathematical learning, and Realistics Mathematic Education (RME) learners.

The results of this analysis will be used as a research guideline in the appropriate foundation of the Worksheets so that it can motivate learners to learn. Student analysis is done by interview and poll of students of SMA Negeri 1 Ampek Angkek. Based on the analysis of the results of the student poll obtained information that the learners still consider mathematics is a difficult lesson because it is very boring, so that the interest of learners less in learning mathematics. But they realize that mathematics is very important and many benefits in everyday life. Learners are less actively asked in the learning process, but the time to ask is given, they prefer to be silent or ask a friend when there is material they find difficult and yet understandable. The collected Data is analyzed in a descriptive way then the information of the learners is sorted and made a guideline in the stage of development or manufacture of prototypes.

Based on information obtained from the students ' analysis results, an effort is made as a solution to solve the problems that have been found. One solution that can solve these problems is by developing RME-based mathematical learning devices in the form of RPP and Worksheets. RME is said to be one of the solutions that can solve the problem, because the characteristics of RME itself can increase the learning interest of learners mathematics so as to improve the ability to solve mathematical problems Learners. The first characteristic of RME is using contextual problems. Learning begins with contextual problems in accordance with the reality or environment facing learners so that they can help learners in the formation of mathematical concepts and can support the mindset of math learners. The second characteristic is to use vertical instruments such as models, schemes, diagrams, and symbols which are bridges for learners to create their own models from real situations to abstract or from informal to formal situations, means students create their own models in resolving contextual problems. The third characteristic is to use student contributions, where learners are given the opportunity to develop a variety of strategies that they have so that all the thoughts or opinions of learners are well-respected or appreciated. The fourth characteristic is the interactive learning process, where teachers give learners the opportunity to communicate their ideas through an interactive learning process. The fifth characteristic is associating with other topic. Linking or integrating between topics or subject matter will make it easy for learners to solve problems.

To further strengthen that RME is one solution that can solve the problem above, can be seen from some research that has been done by researchers. The research of Marzuki Ahmad and Witri Nur Anisa said that the ability to solve the mathematical problem of learners is an ability that needs to be developed in learners and RME approaches can improve student problem solving skills. 


\section{CONCLUSION}

RME-based mathematical learning devices developed in this study only come to the, preliminary research stage that is analysis of learners. The Model that is used in this research consists of three stages, preliminary research, prototyping phase, and assessment phase is very helpful in developing RME-based mathematical learning devices. With RME-based mathematical learning devices, it is expected to improve learners to learn mathematics. Learners become more active in the learning process and are able to relate lesson materials to everyday life or other sciences.

\section{REFERENCES}

[1] Depdiknas. 2003. Undang-undang No. 20 tahun 2003 tentang Sistem Pendidikan Nasional.

[2] Dewi, dkk. 2013. Pengembangan Perangkat Pembelajaran Matematika Realistik untuk Meningkatkan Kemampuan Pemecahan Masalah Peserta didik SMP. Jurnal Pendidikan dan Pengajaran, Jilid 46, Nomor 2, 114-124.

[3] Kusumah, Wijaya .2010. Mengenal Penelitian Tindakan Kelas. Jakarta: PT INDEKS

[4] Marzuki Ahmad, dkk. Pengembangan Perangkat Pembelajaran Matematika Realistik Untuk Membelajarkan Kemampuan Pemecahan Masalah Matematika Siswa SMP.Tahun 2017

[5] Muchlis, EE. Pengaruh Pendekatan Pendidikan Matematika Realistik Indonesia (PMRI) terhadap Perkembangan Kemampuan Pemecahan Masalah Siswa Kelas II SD Kartika 1.10 Padang. Vol X, No 2, Tahun 2012

[6] Mulyati, Asrina (2017). Pengaruh Pendekatan RME terhadap Kemampuan Pemecahan Masalah Peserta didik pada Materi Operasi Hitung Campuran di Kelas IV SD IT Adzkia I Padang.Vol 4. Nomor 1.

[7] Murniaty, LD dkk. Pengembangan Perangkat Pembelajaran Matematika Realistik untuk Meningkatkan Kemampuan Pemecahan Masalah Siswa SMP. Tahun 2013

[8] Plomp, T dan N. Nieveen. 2013. Education Design Research. Enshede: Netherland Institute for Curriculum Development (SLO).

[9] Soedjadi. 2001. Pembelajaran Matematika Berjiwa RME. Makalah disampaikan pada seminar nasional PMRI di Universitas Sanata Darma. Yogyakarta.

[10] Sugiyono. 2010. MetodePenelitianPendidikanPendekatanKuantitatif, Kualitatif, dan R\&D. Bandung: Alfabeta

[11] Thiagarajan, Sivasailam, dkk. 1974. Instructional Development for Training Teachers of Exceptional Children. Washington DC: National Center for Improvement Educational System.
[12] Witri Nur Anisa, dkk. Peningkatan Kemampuan Pemecahan Masalah Dan Komunikasi Matematisk Melalui Pembelajaran Pendidikan Matematika Realistik Untuk Siswa SMP Negeri Di Kabupaten Garut.Tahun 2014 